Volume and Issues Obtainable at Center for Sustainability Research and Consultancy

Journal of Accounting and Finance in Emerging Economies

ISSN: 2519-0318\&ISSN (E):2518-8488

Volume 7: Issue 2 June 2021

ᄃSRC

Journal homepage: www.publishing.globalcsrc.org/jafee

\title{
Impact of CSR On Customer Value Co-Creation Behavior: The Investigation of Moderation Mechanisms
}

Zeeshan Ahmad, Department of Business Administration, Air University, Multan, Pakistan Muhammad Nauman Abbasi, Institute of Management Sciences, IMS, Bahauddin Zakariya University, Multan, Pakistan

*Nadir Munir Hassan Magsi, Department of Business Administration, Air University, Multan, Pakistan

Nosheen Sarwat, Institute of Management Sciences, IMS, Bahauddin Zakariya University, Multan, Pakistan

*Corresponding author's email address: nadir.magsi@aumc.edu.pk

\begin{tabular}{|c|}
\hline ARTICLE DETAILS \\
\hline $\begin{array}{l}\text { History } \\
\text { Revised format: May } 2021 \\
\text { Available Online: Jun } 2021\end{array}$ \\
\hline $\begin{array}{l}\text { Keywords } \\
\text { Corporate } \quad \text { Social } \\
\text { Responsibility, Customer } \\
\text { Value Co-creation, Social } \\
\text { Identity Theory, Telecom } \\
\text { Sector of Pakistan }\end{array}$ \\
\hline
\end{tabular}

JEL Classification $M 0, M 1$

\section{OPEN ACCESS} \begin{abstract}
Purpose: This study focuses on evaluating the contribution CSR activities have in encouraging the customers to co-create value for the organization. This study also assesses the moderation of ECI and OCB between CSR and customer VCC behavior.
\end{abstract}

Design/Methodology/Approach: Using the purposive sampling technique data from 304 employees, managers, and customers simultaneously from the telecom industry in southern Punjab Pakistan. Data analysis were performed through structural equation modeling (SEM) in AMOS v23.

Findings: The findings of the quantitative data show the significant and positive relationship between CSR and customer VCC behavior. ECI and OCB also strengthens the relationship of CSR and VCC. As data was collected only from the telecom sector therefore for the generalizability future research can be conducted towards other stakeholders' orientations in other sectors as health, tourism, and hospitality etc. Moreover, through ECI initiatives, the organization can enhance customer role clarity and perceived value of cocreation, which drive customers to further engage in VCC behavior.

(C) 2021 The authors, under a Creative Commons AttributionNonCommercial 4.0

Recommended citation: Ahmad, Z., Nauman, M., Magsi, N. M. H. and Sarwar, N. (2021). Impact of Csr On Customer Value Co-Creation Behavior: The Investigation of Moderation Mechanisms. Journal of Accounting and Finance in Emerging Economies, 7 (2), 377-391.

\section{Introduction}

In this modern era organizations are encountering severe challenges from the market forces particularly consumer market diversifications, rapid modification of their lifestyles and buying behavior, more elegant demands in term of customization, innovation, lower cost products with higher quality expatiations from the customers end (Ernst et al., 2011). For organizations with complex structures and resistance to change these customer forces present a serious threat and organizations with sustainable strategic stature can convert these forces into value. Service- 
dominant (SD) logic viewpoint in service systems is considered as the core concept (Vargo \& Lusch, 2008) and Vargo \& Lusch (2004) uncovered that apart from the conventional roles the customers also act as a value co-creator for the organizations. According to Zhang et al. (2015) co-creation is all about a dynamic and collaborative relationship between the customer and the organization. Customers act as product or service partners as well as co-creators (Vargo \& Lusch, 2004). This broadens the organizational boundaries by utilizing and outsourcing the creativity and value addition on to customers.

Based on Vargo \& Lusch (2004) SD logic customers possesses the traits of an operant resource by having both tacit and explicit knowledge for value co-creation (VCC) (Gohary \& Hamzelu, 2016; Vargo \& Lusch, 2008). Nevertheless, based on the social identity theory, this behavioral conversion may not happen until the customers have social identification with the organization (Ashforth \& Mael, 1989). This identification can be understood by the degree to which the members and organization assume themselves to share the similar characteristics (Dutton et al., 1994). Such customers exhibit not only devotion, but also organization's offerings more positively (Bhattacharya \& Sen 2003) and play a positive role as co-creator with the organization.

Organizational practices such as corporate social responsibility (CSR) is one of many ways to indicate the stakeholders orientation and address special issues (La Rosa et al., 2017). CSR is considered as the activities where the organizations go beyond their self-interests and legal obligation and do something for the benefits of the society (Mc Williams \& Siegel, 2018). CSR, with a focus on customer-oriented Organizational Citizenship Behavior (OCB) toward its stakeholders (Abugre \& Nyuur, 2015), are found to be attractive for its customers to establish an identity with. (Woodroof et al., 2019). Furthermore, Moosmayer et al. (2019) extended the societal and ethical dimension of SD-logic utilizing business scenarios where VCC and value-inuse are critical elements of CSR (Tilaye, 2019). Thus, deducting from SD logic (Vargo \& Lusch, 2004) and social identity theory (Ashforth \& Mael, 1989), active participation of customers in VCC is rooted into CSR.

The close relationship between frontline service employees (FLSEs) and customers, deemed "employee-customer identification" (Korschun et al., 2014), customers being the operant resource can significantly increase their co-creation behavior (Trong Tuan Luu, 2019). Furthermore, employees' organizational citizenship behavior (OCB) can increase the outcome of CSR activities resulting more customers' VCC behavior with the organization (Hogan et al., 1984). Thus, highlighting the importance of customer's OCB mechanism to co-create.

Previous studies of Luu (2019) and Tuan (2016) considered CSR and Customer VCC Behavior from the servant leadership and relationship marketing Orientation point of view and recommended that future analysis may include moderator variables, like customer-oriented OCB. Bharadwaja et al. (2018) mentioned that self-reported data might be vulnerable to CMV threat. Nonetheless, CMV bias proved to be not a serious risk in their research but still recommended the data collection from multiple sources (i.e., employees, managers, and customers). Furthermore, lack of empirical evidence has been noted linking co-creation to employee-customer identification (ECI) and customers' VCC behavior. To the best of the author's knowledge, no study simultaneously examines CSR, co-creation, with the moderating effects of ECI, and customeroriented OCB.

Our research is an attempt to evaluate the intensity, CSR have in generating customers' VCC behavior. Current study enriches the scholarly attention as mentioned by Karaosmanoglu et al. (2016) and Raza et al. (2020). It also explores the moderation mechanisms of ECI and OCB in the relationship of CSR and customer VCC behavior. As far as managerial implications are concerned, this study enhance the importance of orientation towards stakeholders for CSR activities which instill identification in customers and lead them to become value co-creator for the organization. This will also allow them to personally witness the CSR activities of the organization and they play their role to increase the performance of the organization. 


\section{Literature Review \\ Corporate Social Responsibility (CSR)}

Aguinis (2010) defined CSR as "context-specific organizational actions and policies that take into account stakeholders' expectations and the triple bottom line of economic, social, and environmental performance". CSR represents the ethical values in practice in any organization (Nielsen \& Neergaard, 2018). CSR activities cover the economic, social, and environmental obligations of an organization which are aligned with the ethical theories (Garriga \& Melé, 2013). CSR is a vital element of corporate reputation and has influence on improved financial performance of the company (Reputation Institute, 2015). $22^{\text {nd }}$ annual global CEO survey also concluded that $64 \%$ of CEO says that the CSR is the core element of their corporate strategies and actions (Profile et al., 2017). Additionally, 45\% agreed that in upcoming 5 years their stakeholders expect them to make incremental investments in CSR activities. These managerial intentions are due to increased significance customers are giving to brand's social involvement and socially responsible consumptions (Osei-Frimpong et al., 2019).

\section{Customer VCC Behavior}

The benefit attained through resource integration, activities and interactions with partners in the customer's service network is called customer VCC behavior (McColl-Kennedy et al., 2012 p. 1). People buying the products/services are not only the buyers and users of products or services but also contributes to their delivery and design (Halvorsrud et al., 2016). They go beyond in involvement levels and create value for the organization (Shamim et al., 2016). This VCC behavior takes the forms of both tacit as well as explicit knowledge (Chathoth et al., 2016; Xu et al., 2018). In light of SD logic (Vargo \& Lusch, 2004), customers are always co-creators of value. In this relational exchange they create value for the organizations by active engagement throughout the service value chain (Yi \& Gong, 2013).

Customers are vital actors in service delivery and recognition of its benefits (VCC) (Vargo \& Lusch, 2004). In this way they can be involved in activities, conventionally attached to the company, such as do-it-yourself (Mills \& Morris, 1986), idea generations for service improvements (Bettencourt, 1997), even becoming part-time employees to the organization by cocreating the services (McColl-Kennedy et al., 2012). In SD logic (Vargo \& Lusch, 2004), resource integration could be method of executing VCC.

Customization of new services can generate higher values in a way that customers can directly give their input and create a distinctive personal experience (Chathoth et al., 2016; Xu et al., 2018). Resulting in a higher customer satisfaction (Prebensen \& Xie, 2017; Xu et al., 2018), perceived value of customers' experience (Prebensen \& Xie, 2017), and new services evaluations by the customers (Xu et al., 2018).

\section{Employee-Customer Identification}

Social identity theory assists in explaining causes why individuals create associations with the organizations (Maechler et al., 2016). Keeping in mind that frontline service employees (FLSEs) are at the forefront of interaction with the customers, they are the target of the identification (Hogg \& Terry, 2000). Still in highly job relevant organizations this employee-customer identification (ECI) remains untapped (Ashforth \& Mael, 1989; Buil et al., 2019). This employeecustomer identification induces a sense of belongingness to a social group of customers (Tajfel \& Turner, 2019).

ECI represents the degree to which employees consider customers as their social group fellow members who are most relevant to define their self-concept therefore, it goes beyond conventional perceptions of customer attitude and their traits. This is because only the FLSEs provides the opportunities to evaluate the service homogeneity and associations with the customers (Xu et al., 2018). Other types of ECI can coexist in other professional identities (e.g., accountant, physician) (Cardador \& Pratt, 2018). 


\section{Customer Oriented OCB}

Organizational citizenship behavior (OCB) is coined as an organizationally unrecognized volunteer behavior of an individual that affects the functional performance of an organization (Battal et al., 2020). OCB is categorized as organizational citizenship behavior-individual (OCBI) and organizational citizenship behavior-organization (OCBO) (Williams \& Anderson, 1991). OCBI translates into an allusively beneficial behavior to the organization for example courteous behavior with colleagues or helping co-workers in their work-related challenges. On the contrary, OCBO is translated as the behaviors signifying diligence, job commitment, and faithfulness clearly effecting the organizational productivity and accomplishment, for instance, individual's change management or organizational publicity beyond its boundaries (Williams \& Anderson, 1991).

On the bases of OCB (Bies, 1989), customer-oriented OCB is the volunteer behavior of employees which goes beyond their job descriptions and is not recognized by formal appraisal systems (Zoe, 2007), based on Williams \& Anderson (1991) OCB employees exercising OCB will facilitate and support the colleagues to deliver higher customer services, use innovative ways to help customers in fixing their service related problems, and provide feedbacks for service sustainability (Zoe, 2007).

\section{CSR and Customer VCC Behavior}

S-D logic and social identity approach are used to explain the relationship of CSR and customer VCC. SD logic is widely accepted marketing theory in services sector where the intangible resources, VCC and social connections are key determinants of marketing exchanges (Navarro et al., 2014). Here the prime objective is to enhance the good relations with all the stakeholders by ensuring its alignment with their interests with the organizational objectives (Abela \& Murphy, 2008).

SD logic, as opposed to the value in exchange in goods-dominant logic, stressing upon the valuein use and co-creation of value and resultantly encourage customers and other value creators to market the organization in the market (De Chiara, 2012). CSR activities mainly covers the customer's interests, along with other stakeholders (Buil et al., 2019), results in closer ties between them and more value co-creation for the organization (De Chiara, 2012). In SD logic service in exchange of service is the crucial point (Vargo \& Lusch, 2004) and the organizations practicing CSR incorporate the social concerns to their business operations on volunteer basis(De Chiara, 2012) and thus CSR activities provide an opportunity for VCC.

Karaosmanoglu et al. (2016) has used the social identity theory (Ashforth \& Mael, 1989) to check the effects of CSR on customer behavior. Social identity theory says that individuals struggle to enhance their positive self-esteem by improving their social identity. Social identity approach was used by Ahearne et al. (2005) to develop a model for customer-company identification. Though without formal membership this group identification can still happen (Reed, 2002). Customers without the formal membership can still identify themselves with the organizations only if they find it attractive and competent enough in improving their social identity (Ahearne et al., 2005). Ahearne et al. (2005) mentioned that in this modern age certain organizations do propose such attractive, profound social identities to their consumers so that their self-concept need is fulfilled. Martínez \& Rodríguez del Bosque (2013) found that CSR is imparting appealing and profound social identities for customers. This identification increases when value of CSR activities is aligned with the customer's perceived values. Therefore, whenever the organizations are going beyond their ethical or legal requirements, they feel esteemed and tends to behave positively (VCC behavior) towards the organization due to higher level of identity. Therefore, we can propose that:

H1: CSR is positively related to customer VCC behavior.

\section{Moderating Effects Customer-oriented OCB}




\section{Customer Oriented OCB}

Organizational citizenship behavior (OCB) is coined as an organizationally unrecognized volunteer behavior of an individual that affects the functional performance of an organization (Battal et al., 2020). OCB is categorized as organizational citizenship behavior-individual (OCBI) and organizational citizenship behavior-organization (OCBO) (Williams \& Anderson, 1991). OCBI translates into an allusively beneficial behavior to the organization for example courteous behavior with colleagues or helping co-workers in their work-related challenges. On the contrary, OCBO is translated as the behaviors signifying diligence, job commitment, and faithfulness clearly effecting the organizational productivity and accomplishment, for instance, individual's change management or organizational publicity beyond its boundaries (Williams \& Anderson, 1991).

On the bases of OCB (Bies, 1989), customer-oriented OCB is the volunteer behavior of employees which goes beyond their job descriptions and is not recognized by formal appraisal systems (Zoe, 2007), based on Williams \& Anderson (1991) OCB employees exercising OCB will facilitate and support the colleagues to deliver higher customer services, use innovative ways to help customers in fixing their service related problems, and provide feedbacks for service sustainability (Zoe, 2007).

This new type confirms related studies who advocated for the introduction of customer-oriented citizenship behavior, especially in companies where staff have direct relationships and need to represent the company against external parties (Bettencourt, 1997; Podsakoff et al., 2012). Customer OCBs are in fact highly appropriate for the hospitality industry(Qiu et al., 2019; Zoe, 2007), and are particularly significant in enhancing the level of service to customers, loyalty for customers and, thus, the effectiveness of hospitality.

H2: Customer-oriented OCB has moderating effect on the relationship between CSR and customer VCC behavior.

\section{Moderating Effects employee customer identification}

Organizational identification is termed as the feelings of togetherness with or sense of affiliation to the organization (Ashforth \& Mael, 1989). Another finding from the identification literature is the concept that people usually develop multiple group affiliations and can have dual group identifications simultaneously (Reed, 2002; Van Vaerenbergh \& Orsingher, 2016). Such dual identifications do not prevent the identification with other group, denoting that an employee synchronically can identify him/herself with organization as well as with customers (Hogg \& Terry, 2000). The core job of the employees is to satisfy the customer needs by offering quality services, organizational identification motivated them to practice positive customer oriented behavior (Hughes et al., 2019). Ashforth et al. (2007) pointed out that many organizational psychologists are of the opinion that employees who strongly identify themselves with the organization, when working for the organization, may establish deeper connections with their customers (Ashforth et al., 2007). Additionally, it had also been found that FLSEs who deal their customers with higher level of responsibility play a vital role in organizational success (Garcia et al., 2018). This identification is a source of employee motivation to be responsible and consistent in helping the customer and helps paving the ways of organizational success, therefore this may define the established identification between employees and customers. Therefore, we propose that: behavior.

H3: ECI has moderating effect on the relationship between CSR and customer VCC 


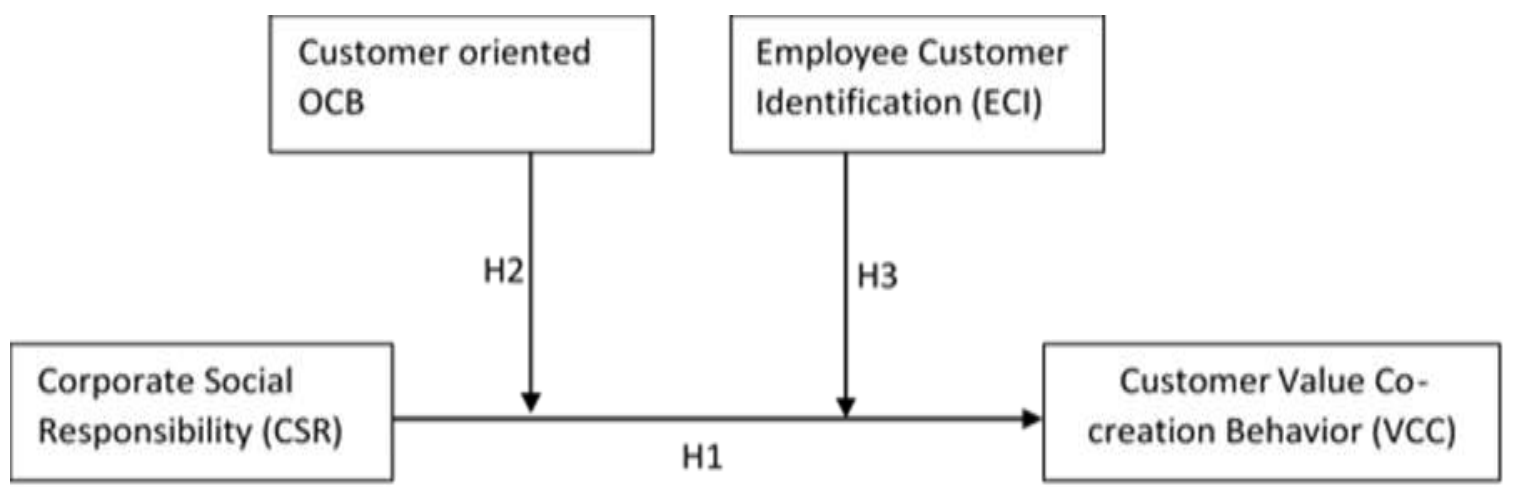

Figure 1 Theoretical Framework

\section{Research design}

The research of this study is descriptive research and cross sectional in nature. The population of this study was urban adults of Southern part of the Punjab province who are customer, front line manager and front-line employee of telecom sector between the age of 16 to above 45 . Participants were users of U-Phone, Jazz/Warid, Zong and Telenor mobile service providers, the majority of the customer, front line manager and front-line employee are involved in telecom sector aging between fifteen to above forty-five and there are five cities (i-e: Multan, Bhawalpur, Rahimyar Khan, D.G Khan, and Jhang). As per the recommendations of Podsakoff et al. (2012) to reduce the chances of potential common method variance (CMV) bias , using the survey questionnaire, we collected the data at three different time intervals. Initially (T1), we collected the data related to CSR \& ECI, along with their demographic data, from the FLSEs of telecom companies. Second, after one month time period (T2) we contacted the managers to collect the data on customer-oriented OCB. Lastly, after one month (T3), customer VCC behavior responses from the customers were collected. The respondents aged 15 to higher than forty-five years were selected due to subsequent reasons: (1) this cluster tends to emphasize diversity (2) this cluster has long been the target of firms needs to develop customer VCC behavior.

We employed purposive sampling technique, from southern Punjab and collected data of 15above 45 years old customers - Multan (23.07\%), Bhawalpur (21.37\%), Rahimyar Khan (19.72\%), D.G Khan (20.39\%) and Jhang (15.45\%). The general response rate was male (65.1\%) and female (34.9\%). Based on the interaction with the FLSEs respondents were asked to choose the most appropriate answer from the 5-point Likert scale, whereas 1 was "strongly disagree" and 5 was "Strongly disagree. Finally, out of 400 collected questionnaires, 304 (76\%) were valid for further analysis.

\section{Measurement Instruments}

A nine (9) items scale from Turker (2009) for measuring CSR was adopted which was divided into three CSR social and non-social, CSR to customers and CSR to employees dimensions respectively. Customer VCC Behavior was measured using a 19 items scale from Yi \& Gong (2013). Customer-oriented OCB was measured using seven adapted items from Zoe (2007) to the managers. Employee-Customer Identification was measured adapting a five-items scale of Homburg et al. (2009). Whereas employee age (years), employee gender, employee qualifications, and service-tenure (years) were taken as the control variables.

\section{Data Results analysis and interpretation}

We used SPSS V23 for preliminary analysis at the same time AMOS version 23 for structural equation modeling (SEM). Using four latent variable and 41 observed variables confirmatory factor analysis (CFA) was conducted in AMOS 23. As per the recommendations of Tabachnick \& Fidell (2012) model fitness indices shown in Table 1.

Table 1 the goodness-of-fit of the CFA measurement model 


\begin{tabular}{llllllllll}
\hline & \multicolumn{1}{c}{ Absolute Fit } & \multicolumn{7}{c}{ Incremental Fit } \\
\hline & $\mathbf{x}$ /df & GFI & AGFI & RMSEA & NFI & RFI & IFI & TLI & CFI \\
\cline { 2 - 9 } Recommendation Levels & $<3$ & $>0.8$ & $>0.8$ & $<0.08$ & $>0.9$ & $>0.9$ & $>0.9$ & $>0.9$ & $>0.9$ \\
Original Model & 1.947 & 0.86 & 0.828 & 0.056 & 0.802 & 0.936 & 0.903 & 0.916 & 0.922 \\
Structural Model & 1.455 & 0.932 & 0.91 & 0.039 & 0.902 & 0.939 & 0.967 & 0.96 & 0.967 \\
\hline
\end{tabular}

Table 2 shows that the reliability and validity of the constructs, and the loadings were greater than the cross-loadings without any considerable cross-loadings that confirms the discriminant validity.

Table 2 Reliability and Validity - Construct

\begin{tabular}{|c|c|c|c|c|c|c|c|}
\hline Codes & $\begin{array}{l}\text { Factor } \\
\text { Loadings }\end{array}$ & SMC & Mean & SD & $\alpha$ & $\mathbf{C R}$ & AVE \\
\hline Corporate social responsibility & & & & 0.681 & 0.824 & 0.702 & 0.521 \\
\hline CSR_STK1 & 0.770 & 0.540 & 3.800 & & & & \\
\hline CSR_STK2 & 0.950 & 0.765 & 3.940 & & & & \\
\hline CSR_STK3 & 0.730 & 0.630 & 3.740 & & & & \\
\hline CSR_CUS1 & 0.900 & 0.849 & 3.850 & & & & \\
\hline CSR_CUS2 & 0.460 & 0.370 & 3.430 & & & & \\
\hline CSR_CUS3 & 0.560 & 0.488 & 3.550 & & & & \\
\hline CSR_EMP1 & 0.940 & 0.786 & 3.960 & & & & \\
\hline CSR_EMP2 & 0.920 & 0.691 & 3.950 & & & & \\
\hline CSR_EMP3 & 0.880 & 0.700 & 3.910 & & & & \\
\hline Customer VCC Behavior & & & & 0.683 & 0.846 & 0.777 & 0.628 \\
\hline Inf_SE_VCC1 & 0.920 & 0.773 & 3.960 & & & & \\
\hline Inf_SE_VCC2 & 0.900 & 0.818 & 3.990 & & & & \\
\hline Inf_SE_VCC3 & 0.870 & 0.736 & 3.990 & & & & \\
\hline Inf_SH_VCC1 & 0.680 & 0.463 & 3.620 & & & & \\
\hline Inf_SH_VCC2 & 0.873 & 0.710 & 3.391 & & & & \\
\hline Res_VCC1 & 0.772 & 0.658 & 4.187 & & & & \\
\hline Res_VCC2 & 0.760 & 0.714 & 3.968 & & & & \\
\hline PI_VCC1 & 0.871 & 0.740 & 3.659 & & & & \\
\hline PI_VCC2 & 0.700 & 0.667 & 3.954 & & & & \\
\hline PI_VCC3 & 0.841 & 0.671 & 4.968 & & & & \\
\hline FB_VCC1 & 0.927 & 0.676 & 4.427 & & & & \\
\hline FB_VCC2 & 0.848 & 0.716 & 4.450 & & & & \\
\hline FB_VCC3 & 0.754 & 0.652 & 3.866 & & & & \\
\hline AD_VCC1 & 0.400 & 0.281 & 3.910 & & & & \\
\hline AD_VCC2 & 0.780 & 0.673 & 4.130 & & & & \\
\hline HP_VCC1 & 0.920 & 0.775 & 4.030 & & & & \\
\hline HP_VCC2 & 0.980 & 0.811 & 4.070 & & & & \\
\hline Tol_VCC1 & 0.930 & 0.757 & 4.000 & & & & \\
\hline Tol_VCC2 & 0.930 & 0.792 & 4.030 & & & & \\
\hline Customer-oriented OCB & & & & 0.736 & 0.778 & 0.731 & 0.589 \\
\hline OCB1 & 0.900 & 0.671 & 3.960 & & & & \\
\hline OCB2 & 0.910 & 0.615 & 3.880 & & & & \\
\hline OCB3 & 0.940 & 0.647 & 4.050 & & & & \\
\hline OCB4 & 0.880 & 0.563 & 3.920 & & & & \\
\hline OCB5 & 0.790 & 0.535 & 3.910 & & & & \\
\hline OCB6 & 0.650 & 0.489 & 3.930 & & & & \\
\hline OCB7 & 0.850 & 0.436 & 3.320 & & & & \\
\hline
\end{tabular}




\begin{tabular}{llllllll} 
Employee customer identification & & & & 0.723 & 0.708 & 0.724 & 0.566 \\
ECI1 & 0.470 & 0.791 & 3.850 & & & & \\
ECI2 & 0.890 & 0.780 & 3.830 & & & & \\
ECI3 & 0.800 & 0.678 & 3.830 & & & & \\
ECI4 & 0.650 & 0.561 & 3.720 & & & & \\
ECI5 & 0.850 & 0.182 & 3.560 & & & & \\
\hline
\end{tabular}

Additionally, discriminant validity was achieved as the AVE value of each construct surpassed its correlations with the other constructs (Fornell \& Larcker, 1981) (Table 3). The reliabilities of the scales were assessed through the composite construct reliability coefficients and AVE (Table 3). Composite reliabilities values of 0.702 (CSR) to 0.777 (VCC), are above the standard limit of 0.70 (Bagozzi \& Yi, 1988). AVE values of 0.521 (CSR) to 0.628 (VCC), are also more than the threshold value of 0.50 (Fornell \& Larcker, 1981). Furthermore, as the discriminant validity condition were fulfilled therefore multicollinearity was not a threat in our data analysis (Fornell \& Larcker, 1981) and the highest values noted were between CSR and customer VCC behavior $(\mathrm{r}=0.792)$.

Table 3 Discriminant Validity Model - constructs

\begin{tabular}{lllllll}
\hline & CR & AVE & CSR & VCC & OCB & ECI \\
\hline CSR & 0.702 & 0.521 & $\mathbf{0 . 7 2 1}$ & & & \\
VCC & 0.777 & 0.628 & 0.113 & $\mathbf{0 . 7 9 2}$ & & \\
OCB & 0.731 & 0.589 & 0.056 & 0.597 & $\mathbf{0 . 7 6 4}$ & $\mathbf{0 . 7 5 2}$ \\
ECI & 0.724 & 0.566 & 0.074 & 0.189 & 0.256 & \\
\hline
\end{tabular}

Note: $\mathrm{CSR}=$ Corporate social responsibility $; \mathrm{VCC}=$ Value co-creation; $\mathrm{OCB}=\mathrm{Customer}$ oriented $\mathrm{OCB} ; \mathbf{E C I}=$ Employee customer Identification

\section{Hypotheses Testing}

This study uses AMOS 23.0 software for analysis, and the maximum likelihood method is used to analyze the structural model of the conceptual model. The results are shown in Table 5. H1: It had been hypothesized that significant relationship exists between consumer's corporate social responsibility (CSR) and consumer oriented VCC. It's proven from the results that $\gamma=0.39$ with $\mathrm{p}<0.01$, is showing the significantly positive relationship between CSR and VCC. The results show that CSR has significant and direct impact on VCC. The interaction value of CSR and OCB was significantly positive $(\mathrm{b}=0.28, \mathrm{p}<0.01)$, which proves our hypothesis $\mathrm{H} 2$. The interaction value of CSR and ECI was significantly positive $(b=0.24, p<0.01)$, which corroborated hypothesis $\mathrm{H} 3$.

Table 4 Results of Hypothesis

\begin{tabular}{llcccc}
\hline Hypothesis & Structural Path & $(\gamma)$ & t-Values & p - Values & Decision \\
\hline H1 & BL<--- BE & 0.392 & 5.639 & $* * *$ & Accepted \\
H2 & VCC<--- CSR_X_OCB & 0.282 & 4.918 & $* * *$ & Accepted \\
H3 & VCC<--_CSR_X_ECI & 0.24 & 4.18 & $* * *$ & Accepted \\
\hline
\end{tabular}

Note: ${ }^{*} \mathrm{p}<0.1 ; * * \mathrm{p}<0.05 ; * * * \mathrm{p}<0.01$

Moderating effects of customer-oriented OCB and Employee Customer Identification.

Table $6 \& 7$ and Fig. $2 \& 3$ exhibit shows the moderation results using the Baron \& Kenny (1986) approach. Outcome clearly show that of these paths are significantly moderated by customeroriented $\mathrm{OCB}$, and therefore re-confirm the stability and strength of the proposed model.

Table 5 Moderating effect of OCB

\begin{tabular}{llllll}
\hline Variables & Hypothesis & $\boldsymbol{\beta}$ & SE & t & P \\
\hline
\end{tabular}




\begin{tabular}{llllllll}
\hline Step 1 & VCC & $<---$ & CSR & 0.333 & 0.058 & 5.74 & $* * *$ \\
& & & & & & & \\
Step 2 & VCC & $<---$ & CSR & 0.172 & 0.071 & 2.417 & 0.016 \\
& VCC & $<--$ & OCB & 0.265 & 0.071 & 3.741 & $* * *$ \\
Step 3 & VCC & $<---$ & CSR & 1.13 & 0.206 & 5.473 & $* * *$ \\
& VCC & $<---$ & OCB & 1.192 & 0.2 & 5.948 & $* * *$ \\
& VCC & $<---$ & CSR_X_OCB & 0.282 & 0.057 & 4.918 & $* * *$ \\
\hline
\end{tabular}

Table 6 Moderating effect of ECI

\begin{tabular}{|c|c|c|c|c|c|c|c|}
\hline Variables & Hypothesis & & & $\beta$ & SE & $\mathrm{t}$ & $\mathbf{P}$ \\
\hline Step 1 & VCC & $<--$ & CSR & 0.333 & 0.058 & 5.74 & $* * *$ \\
\hline \multirow[t]{2}{*}{ Step 2} & VCC & $<--$ & CSR & 0.172 & 0.067 & 2.565 & 0.01 \\
\hline & VCC & $<--$ & ECI & 0.274 & 0.062 & 4.423 & $* * *$ \\
\hline \multirow[t]{3}{*}{ Step 3} & VCC & $<---$ & CSR & 0.941 & 0.195 & 4.821 & $* * *$ \\
\hline & VCC & $<--$ & $\mathrm{ECI}$ & 1.118 & 0.211 & 5.306 & $* * *$ \\
\hline & VCC & $<---$ & CSR_X_ECI & 0.24 & 0.057 & 4.18 & $* * *$ \\
\hline
\end{tabular}

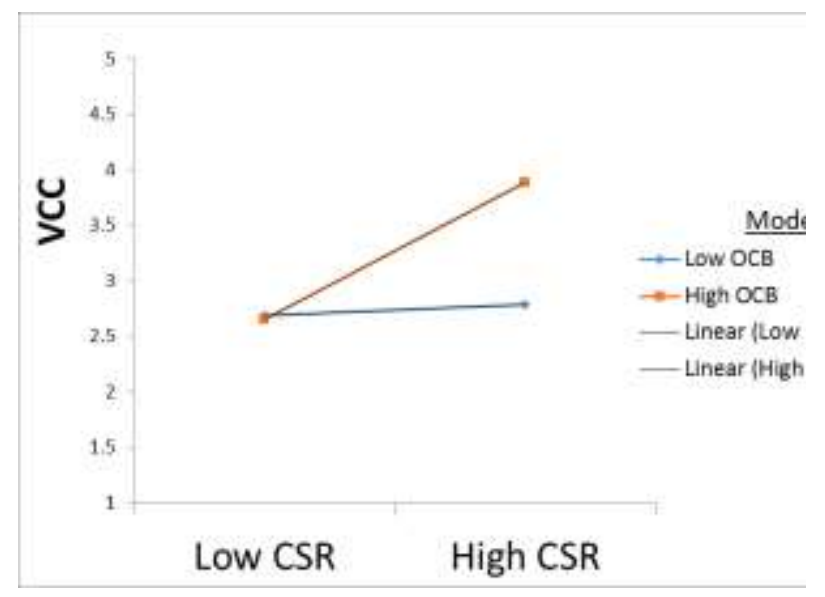

Figure 2 The Moderating Effect of OCB on the Relationship between CSR and VCC

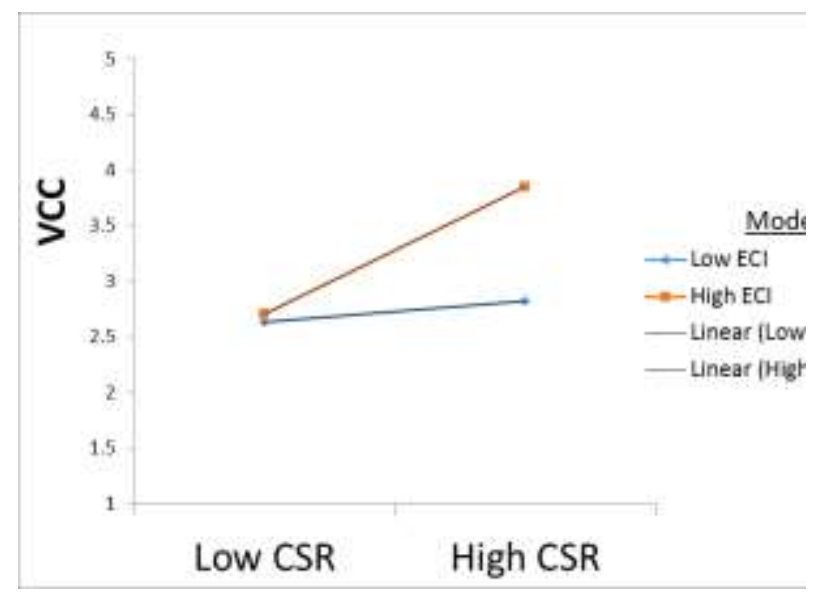

Figure 3 The Moderating Effect of ECI on the Relationship between CSR and VCC 


\section{Discussion}

Our research has multiple theoretical and managerial contributions. First, it extends the use of SD logic and social identity theory to investigate the relationships. Previous work have exhibited that in SD logic customer always act as a value co-creator (Abela \& Murphy, 2008). This work is pioneer to test empirically the impact of stakeholders' pushed CSR activities on customer oriented VCC behavior. Secondly, our research extends the literature of customer-oriented OCB by examining the moderation mechanism between CSR and customer VCC behavior. Prior research have mainly focused on the individual or organizational consequences of customeroriented OCB for example organizational justice (Parris \& Peachey, 2013) whereas we have focused on the marketing related outcomes i.e. customer VCC behavior. Abela \& Murphy (2008) has a found deeper and more comprehensive effect on customer behaviors which can direct customers in value co-creation process with the organizations. This is an indication that collaboration of stakeholder directed forces can mobilize the internal or external operant resources e.g. customers and facilitate its sustainability (Gohary \& Hamzelu, 2016).

Thirdly, ECI as a moderator between CSR and VCC, is not only an increase in relationship marketing literature, at the same time, in SD logic research stream it also create a connection among them (Vargo \& Lusch, 2004). Further this interactive relationship of CSR and ECI to induce VCC makes this work unique from the previous research works on ECI and customer satisfaction (Ngo et al., 2016) or loyalty (Hennig-Thurau et al., 2002). ECI facilities customers to establish bonds with the organizations and later perceive these bonds to shape CSR (Rao et al., 2000), therefore, maximizing the chances that the organization is considered socially responsible and competent enough to shape its social identity.

Lastly, as Pakistan is an emerging economy in which customers are still in early phases of knowing their role as operant resource (Gohary \& Hamzelu, 2016), our findings will be a guide for the customers to know their new and dynamic role for mutual growth of both the organization and the customers.

\section{Managerial Implications}

The current research has several managerial implications. First, CSR initiatives could help build the VCC behavior in the customers. With orientation towards stakeholders, particularly the customer, using the social identity theory (Ashforth \& Mael, 1989) organizations can promote VCC behavior in customers. All CSR activities should be directed towards the sustainability of all the stakeholders and must be visible to them. Because the customers take a notice and evaluate the CSR actions towards them and others. Customer should also be given an opportunity to "see" the employees' motivation which results from the appropriate reward and appraisal, both monetary and non-monetary, they receive for taking part in organization operations. Rather than letting the customer feel only on the basis of CSR activities in advertisements or product packaging the customers should be given an opportunity to observe employees pride, which they get due to their organizations' CSR activities for the society where they have also participated.

Secondly, CSR strategy implementation must not be without the collaboration of HR managers (Ulrich \& Brockbank, 2005), as they design training programs to develop customers' image, in the employees mind, as a value co-creator. FLSEs are in direct contact with the customers and have a strong influence on them therefore, their awareness of customer's being operant resource is vital. Which can guide them to establish relationship with customers by not only solving their problems but also augment blend of CSR values in them and later on transform them into "partial employer" or member of the organization (McColl-Kennedy et al., 2012; Mills \& Morris, 1986) who exhibit organizational commitment (Gruen, 1995) and shares through VCC behavior. Moreover, through ECI initiatives, the organization can enhance customer role clarity and perceived value of co-creation, which drive customers to further engage in VCC behavior (Dong 
et al., 2008).

\section{Limitations and future research path}

Like different investigation, this investigation has a few constraints. To start with, this examination was accomplished with the telecom setting just, which restricts its generalizability. So as to upgrade generalizability of the distinguished connections, the proposed system ought to be tried in different enterprises like - banking, the travel industry and hospitality, health care and so on. Secondly, this investigation doesn't think about the job of sexual orientation contrasts (male and female) in seeing the CSR practices of the organizations, which can be a significant future examination territory. Since the sex contrasts impact the reactions to promoting practices (Melnyk et al., 2009). Lastly, positive relationship between CSR and customer VCC behavior is an indication that other stakeholder forces like corporate (Tuan Trong Luu, 2017; Rahim \& Alam, 2014) or clinical governance (Tuan, 2016) can be introduced as the antecedents.

\section{References}

Abela, A. V., \& Murphy, P. E. (2008). Marketing with integrity: Ethics and the service-dominant logic for marketing. Journal of the Academy of Marketing Science. https://doi.org/10.1007/s11747-007-0062-0

Abugre, J. B., \& Nyuur, R. B. (2015). Organizations' commitment to and communication of CSR activities: Insights from Ghana. Social Responsibility Journal. https://doi.org/10.1108/SRJ06-2013-0066

Aguinis, H. (2010). Organizational responsibility: Doing good and doing well. In APA handbook of industrial and organizational psychology, Vol 3: Maintaining, expanding, and contracting the organization. https://doi.org/10.1037/12171-024

Ahearne, M., Bhattacharya, C. B., \& Gruen, T. (2005). Antecedents and consequences of customer-company identification: Expanding the role of relationship marketing. Journal of Applied Psychology. https://doi.org/10.1037/0021-9010.90.3.574

Ashforth, B. E., \& Mael, F. (1989). Social Identity Theory and the Organization. Academy of Management Review. https://doi.org/10.5465/amr.1989.4278999

Ashforth, B. E., Sluss, D. M., \& Saks, A. M. (2007). Socialization tactics, proactive behavior, and newcomer learning: Integrating socialization models. Journal of Vocational Behavior. https://doi.org/10.1016/j.jvb.2007.02.001

Bagozzi, R. P., \& Yi, Y. (1988). On the evaluation of structural equation models. Journal of the Academy of Marketing Science. https://doi.org/10.1007/BF02723327

Baron, R. M., \& Kenny, D. A. (1986). Baron \& Kenny, 1986. Journal of Personality and Social Psychology.

Battal, F., Durmus, I., \& Cinar, E. (2020). The effects of organizational citizenship behaviors and decision-making styles on transformational leadership behavior. Turkish Studies: International Periodical for the Languages, Literature and History.

Bettencourt, L. A. (1997). Customer voluntary performance: Customers as partners in service delivery. Journal of Retailing. https://doi.org/10.1016/S0022-4359(97)90024-5

Bharadwaja, S., Lee, L., \& Madera, J. M. (2018). Customer evaluations of service-oriented organizational citizenship behaviors: Agentic and communal differences. International Journal of Hospitality Management. https://doi.org/10.1016/j.ijhm.2017.10.021

Bies, R. J. (1989). Organizational Citizenship Behavior: The Good Soldier SyndromeOrganizational Citizenship Behavior: The Good Soldier Syndrome, by OrganDennis W.. Lexington, MA: Lexington Books, 1988, 160 pp., \$21.95, cloth. Academy of Management Review.

Buil, I., Martínez, E., \& Matute, J. (2019). Transformational leadership and employee performance: The role of identification, engagement and proactive personality. International Journal of Hospitality Management. https://doi.org/10.1016/j.ijhm.2018.06.014

Cardador, M. T., \& Pratt, M. G. (2018). Becoming who we serve: A model of multi-layered 
employee-customer identification. Academy of Management Journal. https://doi.org/10.5465/amj.2015.1201

Chathoth, P. K., Ungson, G. R., Harrington, R. J., \& Chan, E. S. W. (2016). Co-creation and higher order customer engagement in hospitality and tourism services: A critical review. International Journal of Contemporary Hospitality Management. https://doi.org/10.1108/IJCHM-10-2014-0526

De Chiara, A. (2012). S-D Logic and CSR: the management of social capital for the value creation in SMEs. Journal of Business Market Management, 5(2), 137-153.

Dong, B., Evans, K. R., \& Zou, S. (2008). The effects of customer participation in co-created service recovery. Journal of the Academy of Marketing Science. https://doi.org/10.1007/s11747-007-0059-8

Dutton, J. E., Dukerich, J. M., \& Harquail, C. V. (1994). Organizational Images and Member Identification. Administrative Science Quarterly. https://doi.org/10.2307/2393235

Ernst, H., Hoyer, W. D., Krafft, M., \& Krieger, K. (2011). Customer relationship management and company performance-the mediating role of new product performance. Journal of the Academy of Marketing Science. https://doi.org/10.1007/s11747-010-0194-5

Fornell, C., \& Larcker, D. F. (1981). Evaluating Structural Equation Models with Unobservable Variables and Measurement Error. Journal of Marketing Research. https://doi.org/10.2307/3151312

Garcia, P. R. J. M., Bordia, P., Restubog, S. L. D., \& Caines, V. (2018). Sleeping with a broken promise: The moderating role of generativity concerns in the relationship between psychological contract breach and insomnia among older workers. Journal of Organizational Behavior. https://doi.org/10.1002/job.2222

Garriga, E., \& Melé, D. (2013). Corporate social responsibility theories: Mapping the territory. In Citation Classics from The Journal of Business Ethics: Celebrating the First Thirty Years of Publication. https://doi.org/10.1007/978-94-007-4126-3_4

Gohary, A., \& Hamzelu, B. (2016). Modeling customer knowledge management to make value co-creation. Business Information Review. https://doi.org/10.1177/0266382116631850

Gruen, T. W. (1995). The outcome set of relationship marketing in consumer markets. International Business Review. https://doi.org/10.1016/0969-5931(95)00026-7

Halvorsrud, R., Kvale, K., \& Følstad, A. (2016). Improving service quality through customer journey analysis. Journal of Service Theory and Practice. https://doi.org/10.1108/JSTP-052015-0111

Hennig-Thurau, T., Gwinner, K. P., \& Gremler, D. D. (2002). Understanding Relationship Marketing Outcomes: An Integration of Relational Benefits and Relationship Quality. Journal of Service Research. https://doi.org/10.1177/1094670502004003006

Hogan, J., Hogan, R., \& Busch, C. M. (1984). How to measure service orientation. Journal of Applied Psychology. https://doi.org/10.1037/0021-9010.69.1.167

Hogg, M. A., \& Terry, D. J. (2000). Social Identity and Self-Categorization Processes in Organizational Contexts. The Academy of Management Review. https://doi.org/10.2307/259266

Homburg, C., Wieseke, J., \& Hoyer, W. D. (2009). Social identity and the service-profit chain. Journal of Marketing. https://doi.org/10.1509/jmkg.73.2.38

Hughes, D. E., Richards, K. A., Calantone, R., Baldus, B., \& Spreng, R. A. (2019). Driving InRole and Extra-Role Brand Performance among Retail Frontline Salespeople: Antecedents and the Moderating Role of Customer Orientation. Journal of Retailing. https://doi.org/10.1016/j.jretai.2019.03.003

Karaosmanoglu, E., Altinigne, N., \& Isiksal, D. G. (2016). CSR motivation and customer extrarole behavior: Moderation of ethical corporate identity. Journal of Business Research. https://doi.org/10.1016/j.jbusres.2016.03.035

Korschun, D., Bhattacharya, C. B., \& Swain, S. D. (2014). Corporate social responsibility, customer orientation, and the job performance of frontline employees. Journal of Marketing. 
https://doi.org/10.1509/jm.11.0245

La Rosa, A. T. De, Santiago-Ortega, R., Medina-Rivera, Z., \& Berrios-Lugo, J. (2017). Corporate social responsibility practices \& programs as a key strategic element in organizational performance. Developments in Corporate Governance and Responsibility. https://doi.org/10.1108/S2043-052320170000011011

Luu, Trong Tuan. (2019). CSR and Customer Value Co-creation Behavior: The Moderation Mechanisms of Servant Leadership and Relationship Marketing Orientation. Journal of Business Ethics. https://doi.org/10.1007/s10551-017-3493-7

Luu, Tuan Trong. (2017). CSR and organizational citizenship behavior for the environment in hotel industry: The moderating roles of corporate entrepreneurship and employee attachment style. International Journal of Contemporary Hospitality Management. https://doi.org/10.1108/IJCHM-02-2016-0080

Maechler, N., Sahni, S., \& Oostrum, M. van. (2016). Improving the business-to-business customer experience. In McKinsey \& Company.

Martínez, P., \& Rodríguez del Bosque, I. (2013). CSR and customer loyalty: The roles of trust, customer identification with the company and satisfaction. International Journal of Hospitality Management. https://doi.org/10.1016/j.ijhm.2013.05.009

Mc Williams, A., \& Siegel, D. (2018). Corporate social responsibility: A theory of the firm perspective. In Business Ethics and Strategy, Volumes $I$ and II. https://doi.org/10.4324/9781315261102-8

McColl-Kennedy, J. R., Vargo, S. L., Dagger, T. S., Sweeney, J. C., \& van Kasteren, Y. (2012). Health Care Customer Value Cocreation Practice Styles. Journal of Service Research. https://doi.org/10.1177/1094670512442806

Mills, P. K., \& Morris, J. H. (1986). Clients as "Partial" Employees of Service Organizations: Role Development in Client Participation. Academy of Management Review. https://doi.org/10.5465/amr.1986.4283916

Moosmayer, D. C., Waddock, S., Wang, L., Hühn, M. P., Dierksmeier, C., \& Gohl, C. (2019). Leaving the Road to Abilene: A Pragmatic Approach to Addressing the Normative Paradox of Responsible Management Education. Journal of Business Ethics. https://doi.org/10.1007/s10551-018-3961-8

Navarro, S., Andreu, L., \& Cervera, A. (2014). Value co-creation among hotels and disabled customers: An exploratory study. Journal of Business Research. https://doi.org/10.1016/j.jbusres.2013.11.050

Ngo, V. D., Janssen, F., Leonidou, L. C., \& Christodoulides, P. (2016). Domestic institutional attributes as drivers of export performance in an emerging and transition economy. Journal of Business Research. https://doi.org/10.1016/j.jbusres.2015.12.060

Nielsen, L. H., \& Neergaard, P. (2018). Value creation from strategic partnerships between companies and NGOs. In Developments in Corporate Governance and Responsibility. https://doi.org/10.1108/S2043-052320180000014001

Osei-Frimpong, K., McLean, G., \& Famiyeh, S. (2019). Social media brand engagement practices: Examining the role of consumer brand knowledge, social pressure, social relatedness, and brand trust. Information Technology and People. https://doi.org/10.1108/ITP-05-2018-0220

Parris, D. L., \& Peachey, J. W. (2013). A Systematic Literature Review of Servant Leadership Theory in Organizational Contexts. Journal of Business Ethics. https://doi.org/10.1007/s10551-012-1322-6

Podsakoff, P. M., MacKenzie, S. B., \& Podsakoff, N. P. (2012). Sources of method bias in social science research and recommendations on how to control it. In Annual Review of Psychology. https://doi.org/10.1146/annurev-psych-120710-100452

Prebensen, N. K., \& Xie, J. (2017). Efficacy of co-creation and mastering on perceived value and satisfaction in tourists' consumption. Tourism Management. https://doi.org/10.1016/j.tourman.2016.12.001 
Profile, I., pwc, MarketLine, Collis, D. J., Montgomery, C. A., \& Carter, S. (2017). 22nd Annual Global CEO Survey CEOs'. Harvard Business Review.

Qiu, S., Alizadeh, A., Dooley, L. M., \& Zhang, R. (2019). The effects of authentic leadership on trust in leaders, organizational citizenship behavior, and service quality in the Chinese hospitality industry. Journal of Hospitality and Tourism Management. https://doi.org/10.1016/j.jhtm.2019.06.004

Rahim, M. M., \& Alam, S. (2014). Convergence of Corporate Social Responsibility and Corporate Governance in Weak Economies: The case of Bangladesh. Journal of Business Ethics. https://doi.org/10.1007/s10551-013-1699-x

Rao, H., Davis, G. F., \& Ward, A. (2000). Embeddedness, social identity and mobility: Why firms leave the NASDAQ and join the New York stock exchange. Administrative Science Quarterly. https://doi.org/10.2307/2667072

Raza, A., Rather, R. A., Iqbal, M. K., \& Bhutta, U. S. (2020). An assessment of corporate social responsibility on customer company identification and loyalty in banking industry: a PLSSEM analysis. Management Research Review. https://doi.org/10.1108/MRR-08-2019-0341

Reed, A. (2002). Social Identity as a Useful Perspective for Self-Concept-based Consumer Research. In Psychology and Marketing. https://doi.org/10.1002/mar.10011

Reputation Institute. (2015). The Global RepTrak ${ }^{\text {TM }}$ 100. The Global RepTrak ${ }^{T M} 100$.

Shamim, A., Ghazali, Z., \& Albinsson, P. A. (2016). An integrated model of corporate brand experience and customer value co-creation behaviour. International Journal of Retail and Distribution Management. https://doi.org/10.1108/IJRDM-06-2015-0079

Tabachnick, B. G., \& Fidell, L. S. (2012). Using multivariate statistics (6th ed.). In New York: Harper and Row.

Tajfel, H., \& Turner, J. C. (2019). The Social Identity Theory of Intergroup Behavior. In Political Psychology. https://doi.org/10.4324/9780203505984-16

Tilaye, S. (2019). The Current Practice of Corporate Social Responsibility in Ethiopia. International Journal of Social Work. https://doi.org/10.5296/ijsw.v6i2.15567

Tuan, L. T. (2016). The chain effect from human resource-based clinical governance through emotional intelligence and CSR to knowledge sharing. Knowledge Management Research and Practice. https://doi.org/10.1057/kmrp.2014.23

Turker, D. (2009). How corporate social responsibility influences organizational commitment. Journal of Business Ethics. https://doi.org/10.1007/s10551-008-9993-8

Ulrich, D., \& Brockbank, W. (2005). HR Value Proposition (Hardcover). In Harvard Business School Press Books.

Van Vaerenbergh, Y., \& Orsingher, C. (2016). Service recovery: An integrative framework and research agenda. Academy of Management Perspectives. https://doi.org/10.5465/amp.2014.0143

Vargo, S. L., \& Lusch, R. F. (2004). Evolving to a New Dominant Logic for Marketing. Journal of Marketing. https://doi.org/10.1509/jmkg.68.1.1.24036

Vargo, S. L., \& Lusch, R. F. (2008). Service-dominant logic: Continuing the evolution. Journal of the Academy of Marketing Science. https://doi.org/10.1007/s11747-007-0069-6

Williams, L. J., \& Anderson, S. E. (1991). Job Satisfaction and Organizational Commitment as Predictors of Organizational Citizenship and In-Role Behaviors. Journal of Management. https://doi.org/10.1177/014920639101700305

Woodroof, P. J., Deitz, G. D., Howie, K. M., \& Evans, R. D. (2019). The effect of cause-related marketing on firm value: a look at Fortune's most admired all-stars. Journal of the Academy of Marketing Science. https://doi.org/10.1007/s11747-019-00660-y

Xu, H., Liu, Y., \& Lyu, X. (2018). Customer value co-creation and new service evaluation: the moderating role of outcome quality. International Journal of Contemporary Hospitality Management. https://doi.org/10.1108/IJCHM-08-2016-0467

Yi, Y., \& Gong, T. (2013). Customer value co-creation behavior: Scale development and validation. Journal of Business Research. https://doi.org/10.1016/j.jbusres.2012.02.026 
Zhang, T. (Christina), Kandampully, J., \& Bilgihan, A. (2015). Motivations for customer engagement in online co-innovation communities (OCCs): A conceptual framework. Journal of Hospitality and Tourism Technology. https://doi.org/10.1108/JHTT-10-20140062

Zoe, S. D. (2007). The influence of service climate and job involvement on customer-oriented organizational citizenship behavior in Greek service organizations: a survey. Employee Relations. 